\title{
Perception of Internal Auditor Independence and the Effect on the Perceived Reliability of Internal Audit Reports in India
}

\author{
Pradeep Gupta ${ }^{1}$ \\ ${ }^{I}$ (PhD Scholar, Department of Commerce Maharaj Vinayak Global University, India)
}

\begin{abstract}
This paper is about Internal Audit Independence. The objective of the study is to critically examine the independence of the Internal Auditors in the Indian Market. This study is concerned about the perception of the internal auditor's independence because it is the perceptions, rather than reality, which determine the credibility of the internal audit reports. Hence, it is important to establish what factors are perceived to impair the internal auditor independence. If the internal auditors are perceived to lack independence, does this have any impact on users' assessment of the reliability of the internal audit reports. This study aims to address these issues. The need for internal auditor independence has been recognized by the Institute of Internal Auditors (IIA), Indian Companies Act, The Institute of Chartered Accountants of India (ICAI), Securities and Exchange Board of India (SEBI) along with the professional accounting bodies worldwide. They have issued guidelines relating to the conduct of the internal auditors in order that independence is maintained. .The study has examined various guidelines issued by regulatory bodies.
\end{abstract}

Keywords: Internal Audit, Internal Auditors, Independence, Perception of Internal Auditors

\section{Introduction}

As per the Institution Internal Auditors (IIA), USA, "Internal Audit (IA) is an independent, objective assurance and consulting activity designed to add value and improve an organization's operations. It helps an organization accomplishes its objectives by bringing a systematic, disciplined approach to evaluate and improve the effectiveness of risk management, control, and governance processes".

Internal auditing departments are led by a Chief Internal Auditor ("CIA"), who generally reports to the Board Audit Committee. The importance of the internal audit function is said to rest on the independence of the internal auditors in carrying out their work. There is a general recognition that the value of internal audit report depends upon the degree to which it has been independently produced. The Internal auditing profession has recognized the need for internal auditor's independence and has identified it as having two components, independence in fact and appearances. The former element has been referred to as being a question of internal auditor's mental attitude or his state of mind. While this element is important element of internal auditor's independence, it is not enough for internal auditors to be independent, for them to think and to act independently. They are reporting to others whose benefit is derived from the reassurance which they give and whose reassurance is conditional on belief in the internal auditor's independence. This is the second element of auditor's independence, that is, the ability of the auditor to be seen by third parties to be independent. This study is related to the second element of auditor independence because it has been argued by many that perceptions, rather than reality, determine the credibility of the internal audit report. The future of the internal audit profession is dependent upon the users' perception of the internal auditor independence. Hence, it is important to establish what factors are perceived to impair the internal auditor independence. Finally, if the internal auditors are perceived to lack independence, does this have any impact on users' assessment of the reliability of the internal audit reports. This paper aims to address these issues.

\section{Literature review}

The Government of India has always taken proactive steps in mandating the internal audit for various establishments though various legislations. During this study of Internal Auditor's independence, the following literatures were reviewed:

1. Guidance provided under section 138 of the new Indian Companies Act 2013: Section 138 of Indian Companies Act 2013 read with Rule 13 Of Companies (Accounts) Rules, 2014, requires certain classes of companies to appoint Internal Auditors. The internal auditors may or may not be an employee of the Company.

2. Guidance provided under section 292A of the Indian companies Act 1956: Under Section 292A of the Companies Act 1956, every public company having certain paid-up capital shall constitute a committee of the Board known as "Audit Committee". The annual report of the company shall disclose the composition of the Audit Committee. The auditors, the internal auditor, if any, and the director-in-charge of finance shall attend and participate at meetings of the Audit Committee but shall not have the right to vote. The Audit 
Committee should have discussions with the auditors periodically about internal control systems, the scope of audit including the observations of the auditors and review the half yearly and annual financial statements before submission to the Board and also ensure compliance of internal control systems.

3. Guidance provided under section $581 \mathrm{ZF}$ of the Indian companies Act 1956 : Section 581ZF of the Companies, Act, 1956 which requires that every Producer company shall have internal audit of its accounts carried out by a chartered accountant, at such interval as in such manner as prescribed in the articles.

4. Guidance provided in Clause 49 of the Listing Agreement issued by the Securities and Exchange Board of India (SEBI): Securities \& Exchange Board of India has mandated complete internal audit on a half yearly basis for stock brokers/trading members/clearing members.

5. IRDA Investment Regulations 2008: IRDA has introduced requirements of quarterly internal audit for insurers.

6. Requirement of Section 302 and 404 of the Sarbanes Oxley Act of 2002: US Companies, having US public as investor needs to comply with the requirements of Section 302 and 404 of the Sarbanes Oxley Act of 2002, which provides guidance on internal controls and internal audit.

7. International Standards for Professional Practice of Internal Audit (IPPF) issued by the Institute of Internal Auditors (IIA): As per the IIA, Internal auditing is an independent, objective assurance and consulting activity designed to add value and improve an organization's operations. It helps an organization accomplish its objectives by bringing a systematic, disciplined approach to evaluate and improve the effectiveness of risk management, control, and governance processes.

8. Standards on Internal Audit, published by the Institute of Chartered Accountants of India (ICAI): The ICAI has established Internal Audit Standard Board whose primary task is to establish standards and provide guidance on the Internal Audit.

From the review of the above literature, it is clear that Internal Audit plays a very important role in the Governance, Risk Management and Controls of any company. All the above legislations provides for the independence of the Internal Audit. Hence, we may infer that the success of the internal audit lies in its independence- both in fact and appearance.

\section{III. objectives of the study}

1. To examine the effects of selected variables on the perception of auditor independence.

2. To examine the effect of these perceptions on the perceived reliability of the internal audit report.

3. To explore the reason for such perceptions.

\section{Population for the research}

Section 177 of the Indian Companies Act, 2013 (Previously Section 292A of the Companies Act, 1956) requires the following to constitute an audit committee and require the internal auditor to attend and participate in the meetings of such audit committees:

1. Every listed company

2. Unlisted public companies with paid up capital not less than INR 10 crores

3. All private limited companies with paid up share capital not less than INR 20 crores or more

4. All companies with paid up share capital of below the threshold limit mentioned in (2) and (3) above, but with public borrowings from financial institutions, banks or public deposits of rupees INR 50 crores or more.

The targeted population for the study thus includes the following:

1. Chief Internal Auditors (CIA) / Chief Audit Executives (CAE)

2. Staff of internal Audit Departments (IADs)

3. Staff of Big 4 Accounting Firms who are practicing as Internal Auditors

4. Staff of Non- Big 4 Accounting Firms (Small and Medium firms) who are practicing as Internal Auditors

5. Audit Clients like Chief Risk Officer, Chief Financial Officer and other key executives

The above groups were chosen based on previous research which has identified them as the primary users of internal audit reports and has shown that they rely on internal audit reports to reach appropriate decisions. In addition, these groups have been identified in previous' studies as sophisticated users and on that basis their perceptions of internal audit independence and the impact that such perceptions have on their assessment of the internal audit reports statements are worthy of study. 


\section{Findings and analysis}

The collection of data was primarily through email questionnaires to 75 individuals. The questionnaire sent to Auditees had 30 Questions and the questionnaire sent to Auditors had 18 questions. Different sets of questions were used based on the usage of the internal audit reports of the user category.

Of the total 75 questionnaires emailed, 56 were responded, a response rate of 74.67 percent. The email response was very satisfactory. It was much higher than normally can be expected in an email questionnaire. A great deal of interest was expressed in the research, with approximately 87.5 per cent ( 49 out of 56 respondents) requesting a summary of the results. The summary of respondents is as below:

Table III.1: Analysis of the Response Received

\begin{tabular}{|c|c|c|c|}
\hline $\begin{array}{c}\text { Category Based on } \\
\text { Questionnaire }\end{array}$ & Sample selected & Response Received & Percentage \\
\hline Auditors & 45 & 32 & 71.11 \\
\hline Auditees & 30 & 24 & 80.00 \\
\hline Total & $\mathbf{7 5}$ & $\mathbf{5 6}$ & $\mathbf{7 4 . 6 7}$ \\
\hline
\end{tabular}

Table III.2: Graphical Representation of Response Received

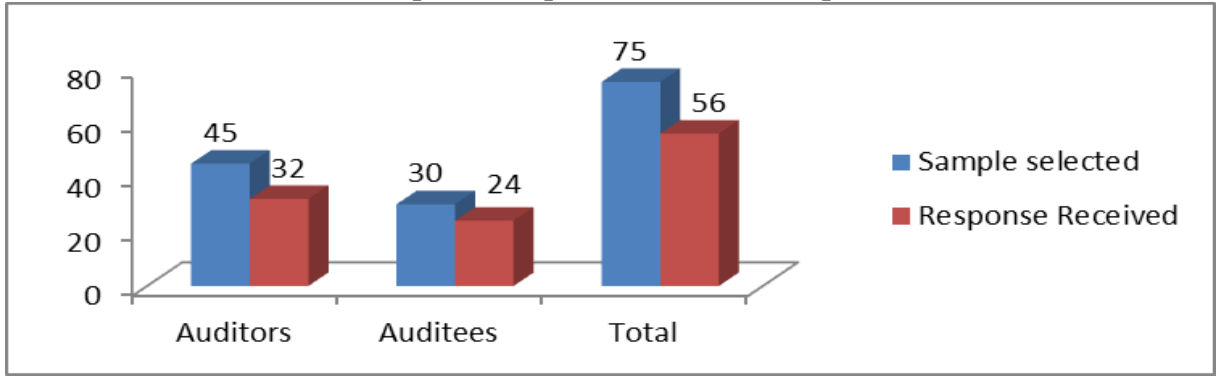

In this paper, we are focusing only on 4 important questions. In the first important question in the research questionnaire, it was asked to the audit clients about the independence of the CIAs. The exact question was "In your view, is the CIA independent"? 22 out of 24 respondents in the category of "auditees" representing 92 percent of the respondents believed that the CIAs in their organization are independent.

Table: III.3: Independence of CIA

\begin{tabular}{|l|l|l|}
\hline Category & Response Received & Percentage \\
\hline Yes & 22 & 91.67 \\
\hline No & 2 & 8.33 \\
\hline Total & $\mathbf{2 4}$ & $\mathbf{1 0 0}$ \\
\hline
\end{tabular}

In another question with respect to the perception of the internal audit function, the research question was, "Would you agree to the statement that one's perception of the Internal Auditor is influenced by how they perceive his role in the company"? The question was asked to both auditors and auditees. 46 out of 56 respondents, representing eighty two percent, believe the one's perception of the internal audit is influenced by their perception in their role. The summary of the response to this question is as below:

Table: III.4: Perception of Auditor

\begin{tabular}{|l|l|l|}
\hline Category & Response Received & Percentage \\
\hline Yes & 46 & 82.14 \\
\hline No & 10 & 17.86 \\
\hline Total & $\mathbf{5 6}$ & $\mathbf{1 0 0}$ \\
\hline
\end{tabular}

Another question which was asked in the research was "If you perceived the internal auditor not to be independent, how would this impact on your assessment of the reliability of the internal audit reports?" In the response to this question, more than half of the respondents were of the opinion that if they perceive that the internal auditors were not independent; this would impact their assessment of the reliability of the internal audit reports. The detail responses to this question are presented below in the table. 
Table: III.5: Independence Vs Impact on Reliability of Internal Audit Reports

\begin{tabular}{|l|c|c|}
\hline Category & Response Received & Percentage \\
\hline Decrease significantly & 10 & 41.67 \\
\hline Decrease to some extent & 4 & 16.67 \\
\hline Remain Constant & 1 & 4.17 \\
\hline Increase Significantly & 7 & 29.16 \\
\hline Increase to some extent & 2 & 8.33 \\
\hline Total & $\mathbf{2 4}$ & $\mathbf{1 0 0}$ \\
\hline
\end{tabular}

The results from the email questionnaire are presented above. The respondents were both Auditees and Auditors who were directly or indirectly associated with the internal audit activities, having had at least five years' experience in their role. The majority of respondents stated that they used internal audit reports and considered them to be important, for decision making purposes. When asked whether they had ever previously suspected a lack of internal auditor independence, more than half of the respondents replied in the affirmative. The most frequent circumstances associated with these suspicions were the internal audit was performed by inhouse internal auditors and the management has influence over the internal audit department. The majority of the respondents did consider the independence of the internal auditors when making a decision on internal control framework. In relation to those who did, the majority stated that if they perceived the auditor not to be independent, they would not have relied on their reports. The final issue addressed was the potential effects on the response of respondents profile and their previous suspicions of a lack of internal auditor independence. Those respondents who had previously suspected a lack of internal auditor independence were more concerned by the issues addressed in the study than those who had not.

\section{Conclusion}

The focus of this research has been on perception of internal auditor independence and the reliability of internal audit reports as held within the commercial environment in India. Chief Internal Auditors, Staff of Internal Audit Departments, Staff of Auditing Firms and Auditees such as Chief Risk Officer, Chief Financial Officer, Head of Compliance and other key executives of the Indian corporate house were selected as representatives of the commercial environment in Indian Market. For the purposes of this study, internal auditor independence was defined as the auditor's ability to be, and to be seen to be, objective and impartial, that is, free from any bias towards any of the parties in relation to whom he or she is acting. Information was deemed to have the quality of reliability when it is free from material error and bias and can be depended upon by users to represent faithfully in terms of valid description that which it either purports to represent or could be reasonably be expected to represent. Data was collected using an email questionnaire. The results from the study showed that there was some overall concern as to the independence issues addressed among both questionnaire respondents and interviewees and they were generally in line with previous empirical research. However, these concerns were rarely overwhelming in strength, and notably not so in respect to the provision of other services. Not surprisingly, these concerns were stronger among-those respondents who had had specific occasion to doubt internal auditor independence. This study raised a number of important issues which should be considered by the internal auditing profession if it wishes to continue to be self-regulated. For the profession to maintain selfregulation, it must provide users a confidence that high standards are being maintained. Implicit in the maintenance of such standards is the notion that internal auditors are not only independent but that they are seen by users of internal audit reports to be independent. Hence, the internal audit profession must continue to research and redefine independence.

\section{References}

[1] The Definition of Internal Audit as per the mandatory guidelines issued by the Institute of Internal Auditors (the IIA)

[2] The Definition of Internal Audit as per Institute of Chartered Accountants of India

[3] The Essential Handbook of Internal Auditing, 2005 Edition

[4] Standards on Internal Audit, published by the Institute of Chartered Accountants of India (ICAI)

[5] Guidance on Risk based Internal Audit, by the Institute of Chartered Accountants of India (ICAI)

[6] Role of Internal Auditors as defined in the Indian Companies Act 2013,

[7] Role of Internal Auditos as defined in the Indian Companies Act 1956

[8] Guidelines on Internal Control Framework provided by the Committee of Sponsoring Organization of the Threadway Committee (COSO)

[9] Guidelines on Assessment of Internal Control in The Sarbanes-Oxley Act of 2002

[10] Guidance by Pricewaterhouse coopers for Internal Audit

[11] Brink, V.Z., and J.A. Cashin, Internal Auditing (New York: Ronald Press, 1958)

[12] Brink, V.Z., and H.N. Witt, Modern Internal Auditing (New York: John Wiley \& Sons, Inc., 1982).

[13] Carey, J.L., The Rise of the Accounting Profession: From Technician to Professional (New York: American Institute of Certified Public Accountants, 1969).

[14] Chapman, C., and U. Anderson, Implementing the Professional Practices Framework (Altamonte Springs, FL: The Institute of Internal Auditors, 2002). 
[15] Smith, C.A., Internal Audit Control (Austin, TX: University Cooperative Society, 1933).

[16] Sawyer, Lawrence (2003). Sawyer's Internal Auditing 5th Edition. Institute of Internal Auditors IIA Article on "Getting a Leg Up"

[17] A.J. Briloff, "Old Myths and New Realities in Accounting"

[18] A. Bryman, "Quantity and Quality in Social Research", London

[19] M.D. Bayles, "Professional Ethics", California: Publishing Wadsworth 